IQTISHADIA

12,2

266

\title{
Analysis of Millennial Generation Behavior in Consuming Halal Products: Structural Equation Model-Partial Least Square (SEM-PLS) Method
}

\author{
Ahmad Zaenal Arifin \\ Diponegoro University, Semarang \\ kevin.filsafat@gmail.com \\ Annisa Nur Salam \\ Diponegoro University, Semarang \\ annisa.nursallam95@gmail.com
}

\begin{abstract}
The elevated demand of Muslim consumers for halal products is a business opportunity for producers or companies. So that attention to consumer behavior of halal products is part of market valuation that is important for achieving success in the halal industry. Meanwhile, the millennial generation will have an influence in determining the trend of product use especially since entering the digital era. So it is important to conduct further studies on the behavior of the millennial generation in consuming halal products. This research was conducted by collecting data through distributing questionnaires to 100 respondents classified as millennial generation. Then the data collected is processed with Structural Equation Modeling-Partial Least Square (SEM-PLS) and gives conclusion that the interest of millennial generation in buying halal products is influenced by Islamic branding and individual religiosity factors. While the satisfaction of the millennial generation in consuming halal products is influenced by the price factor of these products, Islamic branding and religiosity factors. Furthermore, Islamic branding indirectly influences the buying interest and satisfaction of the millennial generation in consuming halal products through a variable mediating religiosity. Therefore, Islamic branding is an urgent matter that must be fulfilled for companies that have a focus on the development of halal industrial.
\end{abstract}

\section{Keywords:}

Buying Interest, Consumer Satisfaction, Religiosity, Price, Islamic Branding, Millennial Generation, SEM-PLS

\section{INTRODUCTION}

Currently halal industry is a new economic growth sector in the global world. Indonesia as the country with the largest Muslim population in the world is one of the potential halalindustrial markets. The halal industry is certainly not 
only about food, but includes the pharmaceutical industry, cosmetics, health products, and service sector components such as logistics, marketing, printing and electronic media, packaging, and branding (Elasrag, 2016). The elevated demand of Muslim consumers for halal products is a business opportunity for producers or companies (Walker, 2007). So that attention to consumer behavior of halal products is part of an important market assessment as one of the main factors achieving success in the halalindustry. Furthermore Sungkar (2011) underlined that the consumer response to halal products is an important determinant in viewing the potential and development of halal industries today.

Consumer behavior is a study that examines how individuals make decisions to spend available and owned resources (time, money and effort) to obtain goods and services that will be consumed (Schiffman and Kanuk, 2007 in Suryani, 2012). Setiadi (2013) argues that consumer behavior has a dynamic nature, which means that it can change and move all the time. Several studies on consumer behavior of halal products have been carried out. Stitou and Rezgui (2012) stated that there were studies conducted on 223 respondents. The results of the study concluded that $56 \%$ of respondents from the study stated that they did not buy a product if they were doubtful about the alloweness of the product. And $87 \%$ of respondents indicated a willingness to pay more for truly halal products. Kotler (2009) suggests that consumer behavior is closely related to the marketing sector. This is because consumer behavior is a reflection of demand for goods. The purpose of marketing is to fulfilland satisfy the needs and desires of target customers in a way that is better than competitors, so marketers must always view the emergence of customer trends that indicate new marketing opportunities. When observing customer trends, this time is very much influenced by the development of technology or commonly referred to as the digital era. The digital era has changed the character and behavior of consumers who were born and grew in this era, where generations are familiar with the digital era as they are called the Millennial generation.

Millennial generation have different tastes and behaviors in purchasing and how to consume available products or services. Today is the time when the millennial generations as the majority have entered the workforce. Their income is relatively high and grows rapidly, determining the desirability of the characteristics of present and future generations, thus increasingly affecting business and economic markets. Millennial generations will have an influence in determining the trend of product use especially since entering 
IQTISHADIA

12,2

268

the digital era. With digital technology, millennial generations are also very active in using social media and online media to interact with their chosen brands. From the results of surveys in developing countries, $83 \%$ of millennial generations will not be interested in using products if the providers are not able to provide the best experience for them.

Based on the background described, it becomes interesting to conduct further analysis of the consumption behavior of the millennial generation, especially in consuming halal products. Specifically this research has a purpose: First, to observe how far the millennial generation uses digital technology in its consumption activities. This is seen from the Millennial generation in the use of technology in payment, the use of technology in ordering products and shopping activities online. Second, this research aims to review how far the millennial generation has an attitude of halal awareness (halal awareness) in consuming products. This is viewed from their knowledge of halal logos and alloweness checking activities of a product before consuming it. Third, this research further aims to determine the effect of price variables and Islamic branding on buying interest and satisfaction in the consumption of halal products that are perceived by Millennial generation. Fourth, in this study also examined whether the variables of religiosity can affect the millennial generation both directly and indirectly to buying interest and perceived satisfaction of consumption.

\section{LITERATUR REVIEW \\ Theoretical Framework}

Buying interest is the tendency of consumers to buy a brand or take actions related to purchasing as measured by the level of possibility of a consumer making a purchase (Meltha, 1994). Fredinand (2006) identifies the interest of buying consumers from various indicators as follows:

a. Transactional interest, namely the tendency of someone to buy a product;

b. Referential interest, namely the tendency of someone to refer products to others;

c. Preferential interest, which is an interest that describes the behavior of someone who has a primary preference for the product. This preference can only be replaced if something happens with its preference product;

d. Explorative interest, namely an interest that describes the behavior of someone who is always looking for information about the product they 
are interested in and is looking for information to support the positive characteristics of the product.

Analysis

of Millennial

Generation

Kotler (2005) defines consumer satisfaction as a variable that is closely related to the quality of products and services produced by businesses, where a high level of product quality will result in higher customer satisfaction as well. Consumer satisfaction for a product can be seen after purchasing the product and will affect the next consumer behavior. If the consumer feels satisfied, the next behavior is marked by making a repeat purchase with the same product.

Price is the amount of money charged to a product. Or in other words the total of the values exchanged by consumers for the benefits of having or using the product (Kotler and Armstrong, 2001).

Islamic branding is the use of names relating to Islam or showing a halal identity for a product whether it is a particular good or service (Baker, 2010).

Stark and Glock (1968) in Astogini (2011) define religiosity in five dimensions, namely:

a. Ritual dimension; namely an aspect that measures the extent to which a person performs his ritual obligations in the religion adopted. For example; going to a place of worship, personal prayer, fasting and others. This ritual dimension is the behavior of diversity in the form of worship in the form of religious ceremonies.

b. Ideological dimension; which regulates the extent to which a person accepts things that are dogmatic in his religion. For example; accept the existence of God, angels and demons, heaven and hell, and so on. In the context of Islamic teachings, this ideological dimension concerns one's belief in the truth of their religions. All teachings that lead from the Qur'an and hadith must be guidelines for all areas of life. Diversity in terms of this aspect, for example, the dedication of dedicating themselves to the community who convey amar ma'ruf nahi mungkar and other amaliyah is carried out sincerely based on high faith.

c. Intellectual dimension; that is about how far someone knows, understands, and understands the teachings of his religion, and the extent to which a person wants to carry out activities to further increase his understanding in religious matters related to his religion. Broadly, this intellectual dimension indicates the level of one's understanding of religious doctrines about the depth of the religious teachings that he embraces. The knowledge a person has will make him or her think more broadly so that religious behavior will be more directed. 
IQTISHADIA

12,2

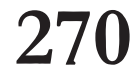

d. Experience dimension; related to how far the Muslim level feels and experiences religious feelings and experiences. In Islam this dimension is manifested in the feeling of being close to God, the feeling of prayer is often fulfilled, a feeling of calm because of the blessing of God, the feeling of trust, the feeling of solemnity when praying, the feeling of being thrilled when hearing the call to prayer or the verses of the Qur'an, feeling thank God, feeling received a warning or help from God.

e. Dimension of consequences; In this case it relates to the extent to which a person wants to commit to his religious teachings in daily life. For example; helping others, being honest, willing to share, not steal, etc. This aspect is different from the aspect of ritual. The ritual aspect is more on religious behavior that is worship/adoration while the commitment aspect is more directed at the human relationship with each other within the framework of the religion adopted. In essence, this dimension of consequences is approaching to the social aspect. Considering from this dimension all activities related to the general community are worship. This is inseparable from comprehensive Islamic teachings, concerning all the principles of life.

\section{Previous Research}

To build a research framework a review of several similar studies conducted in advance is needed. Aditi (2017) in its research concluded that the factors that have a positive and significant influence on customer satisfaction are product innovation, price, and halal certification. Furthermore, he also examined these three factors for repurchase interest, and all three positively and significantly influenced consumers' repurchase interest. And after further examination, customer satisfaction also affects the positive and significant repurchase intention. Research with a similar theme was carried out by Nasrullah (2015) and gave results that Islamic branding can significantly influence consumers in choosing a product. And religiosity as a moderating variable turns out to weaken the relationship between the two.

Adiba et al. (2018) conducted a research on the $\mathrm{Y}$ generation, the results of the study revealed that halal knowledge, Islamic religiosity, and attitude partially had a positive and significant effect on the behavior of Muslim consumers of halal cosmetic users in Surabaya. Halal knowledge and Islamic religiosity variables partially have no effect on consumer behavior, while attitude partially has a positive and significant effect on the behavior of Muslim generation Y users of halal cosmetics in Surabaya.

Syahputra and Hamoraon (2013) in their research concluded: first, the role of the MUI (Majelis Ulama Indonesia) in supervision and socialization 
of food products to the community in Perbaungan District was satisfactory. Analysis Second, the existence of a halal label in the packaging of food products is one of the factors that influence consumers to buy. Third, from the results of the descriptive analysis conducted it can be concluded that the responses of the respondents to the statements addressed to them are very satisfying, this shows that the knowledge of halal labeled food products is quite high.

Haider (2015) in his research concluded that halal marketing has the highest contribution to the purchase intention of halal products. In addition, halal marketing has a positive and significant relationship to the awareness of halal products. His research identifies that religious beliefs are the smallest factors that contribute to the purchase intention of halal products. His research also found that halal certification and logos were able to convince customers that the product was Halal. Consumers want food products that have a Halal logo on it. They are willing to pay more prices to buy halal products.

\section{Research Framework}

Based on the theoretical framework and previous research conduected, the framework of this research can be seen as follows:

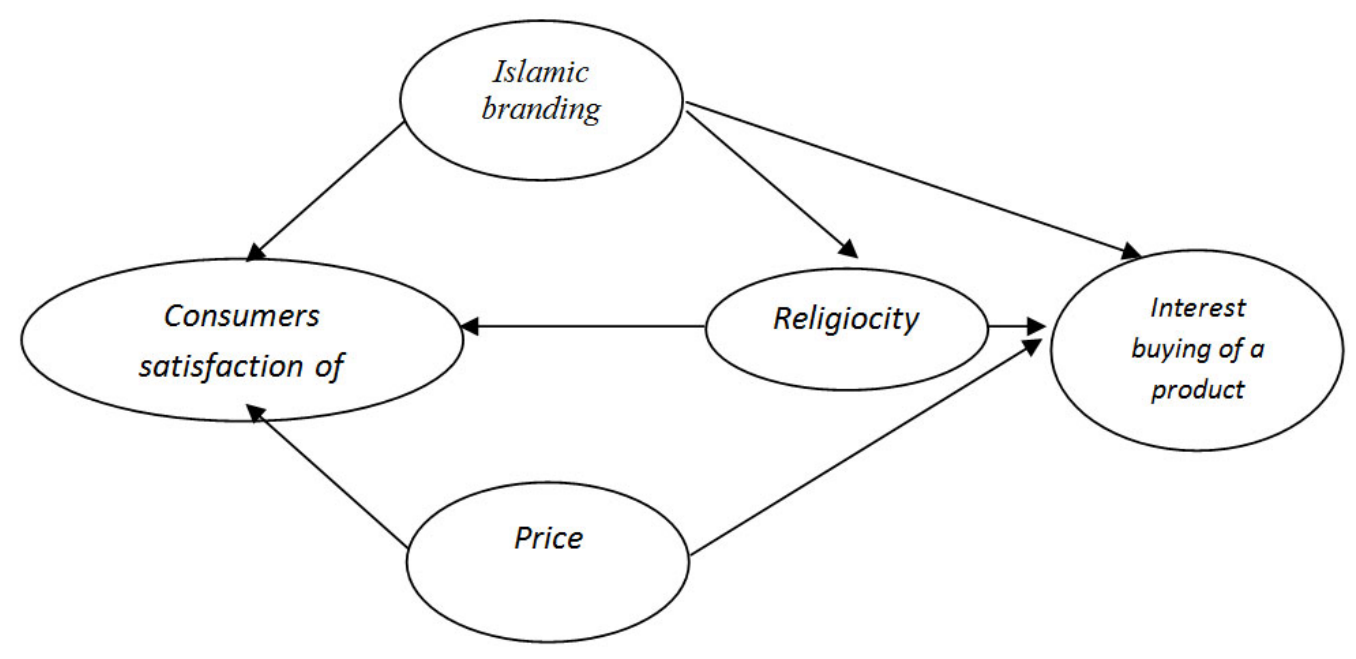

Fig. 1. Research framework

\section{RESEARCH METHODS}

\section{Samples and Sampling}

This study uses 100 samples of Millennial generations scattered in various regions in Indonesia. Data collection is carried out by distributing questionnaires. The sampling method used is purposive sampling. According 
IQTISHADIA

12,2

272

to Umar (2011), purposive sampling is a method of selecting samples based on certain characteristics considered to have relevance to the characteristics of the population that were known beforehand. The sample characteristics used in this study are Muslims who belong to the Millinneal generation or generations who are currently between 18 and 38 years old. This is because the Millennial generation is a group of generations born between 1980 and 2000 (Goldman Sachs Global Research, 2017).

The number of samples is determined by the approach used by Cohen (1992) by considering the statistical power and effect size when determining the sample size. Or more specifically it can be carried out by looking at the number of the biggest arrows regarding one construct, then determining the level of significance used, and the last is the minimum that will be used. The following are references used by Cohen (1992) in determining the sample size with the SEM model (Sholihin, 2013: 13):

\begin{tabular}{|c|c|c|c|c|c|c|c|c|c|c|c|c|}
\hline \multirow{4}{*}{$\begin{array}{l}\text { Minimum } \\
\text { Number of } \\
\text { Arrows } \\
\text { Pointing of } \\
\text { a Construct }\end{array}$} & \multicolumn{12}{|c|}{ Significance Level } \\
\hline & \multicolumn{4}{|c|}{$1 \%$} & \multicolumn{4}{|c|}{$5 \%$} & \multicolumn{4}{|c|}{$10 \%$} \\
\hline & \multicolumn{4}{|c|}{ Minimum $R^{2}$} & \multicolumn{4}{|c|}{ Minimum } & \multicolumn{4}{|c|}{ Minimum } \\
\hline & 0,1 & 0,2 & 0,5 & 0,75 & 0,1 & 0,25 & 0,5 & 0,75 & 0,1 & 0,25 & 0,5 & 0,75 \\
\hline 2 & 158 & 75 & 47 & 38 & 110 & 52 & 33 & 26 & 88 & 41 & 26 & 21 \\
\hline 3 & 176 & 84 & 53 & 42 & 124 & 59 & 38 & 30 & 100 & 48 & 30 & 35 \\
\hline 4 & 191 & 91 & 58 & 46 & 137 & 65 & 42 & 33 & 111 & 53 & 34 & 27 \\
\hline 5 & 205 & 98 & 62 & 50 & 147 & 70 & 45 & 36 & 120 & 58 & 37 & 30 \\
\hline 6 & 217 & 103 & 66 & 53 & 157 & 75 & 48 & 39 & 128 & 62 & 40 & 32 \\
\hline 7 & 228 & 109 & 69 & 56 & 166 & 80 & 51 & 41 & 136 & 66 & 42 & 35 \\
\hline 8 & 238 & 114 & 73 & 59 & 174 & 84 & 54 & 44 & 143 & 69 & 45 & 37 \\
\hline 9 & 256 & 119 & 76 & 62 & 181 & 88 & 57 & 46 & 150 & 73 & 47 & 39 \\
\hline 10 & 256 & 123 & 79 & 64 & 189 & 91 & 59 & 48 & 159 & 76 & 49 & 41 \\
\hline
\end{tabular}

Fig. 2. Guidance of the Determination of Samples Size SEM Model

Based on Figure 2, the minimum number of samples in this study was 59 samples. This is based on the number of arrows that lead to one construct that is three arrows, then the minimum amount of R-square used is 0.25, and the significance used is $5 \%$. The number of samples used in this study is 100 samples. This is carried out because according to Sholihin (2013), the larger the sample, it will increase the accuracy and consistency of SEM-PLS estimation results.

\section{Variables and Indicators}

In SEM analysis there are two main variables, namely latent variables and observed variables. Sholihin (2013) explains that latent variables 
are variables that cannot be measured directly, but the indicator must be measured first. In latent variables there are exogenous latent variables and endogenous latent variables. Exogenous latent variables are variables which values are determined by other variables outside the model or not subject to arrows. While endogenous latent variables are latent variables which of Millennial Generation values are determined by other variables in the model or subject to arrows. The observed variables are variables that are measured empirically and are often referred to as indicators. Furthermore Wijanto (2008) explained, in the survey method using a questionnaire, each question on the questionnaire represented an observed variable indicator.

he variables used in this research can be seen as follows:

Table 1

Variable and Indicator

\begin{tabular}{|c|c|c|}
\hline No. & Variables & Indicators \\
\hline 1 & $\begin{array}{l}\text { Satisfaction of } \\
\text { consuming halal } \\
\text { products }\end{array}$ & $\begin{array}{l}\text { Willingness to buy products even though the price is expensive } \\
\text { Quality of products in accordance to expectation } \\
\text { Interested again to buy same products } \\
\text { Ready to recommend the product to another person }\end{array}$ \\
\hline 2 & $\begin{array}{l}\text { Interesting to buy halal } \\
\text { products }\end{array}$ & $\begin{array}{l}\text { Always having desire to use halal products } \\
\text { Having a plan always to use halal products } \\
\text { Halal products has become a necessity }\end{array}$ \\
\hline 3 & Islamic branding & $\begin{array}{l}\text { Having Halal logo } \\
\text { Using termination of Arabian/syariah/Islamic/halal } \\
\text { Applying Islamic values } \\
\text { Distributing profit partially for social fund } \\
\text { Promotion for memorizer/reader of Quran }\end{array}$ \\
\hline 4 & Religiosity & $\begin{array}{l}\text { Dimension of ritual } \\
\text { Ideology } \\
\text { Intellectual } \\
\text { Experience } \\
\text { Consequences }\end{array}$ \\
\hline 5 & Price & $\begin{array}{l}\text { Affordable price } \\
\text { Compete price } \\
\text { Quality of price }\end{array}$ \\
\hline
\end{tabular}

The variables used are measured through predetermined indicators using a Likert scale. According to Umar (2011), the Likert scale relates to statements about a person's attitude toward something, for example agreedisagree, happy-not happy. The Likert scale used in this study is as follows: 
IQTISHADIA

12,2

274
Table 2

Value of Likert Scale

\begin{tabular}{lll}
\hline No. & Alternative answer & Score \\
\hline 1 & Highly agree & 4 \\
2 & Agree & 3 \\
3 & Disagree & 2 \\
4 & Highly not agree & 1 \\
\hline
\end{tabular}

\section{Techniques of Data Analysis}

Data analysis method used in this research is Structural Equation ModelPartial Least Square (SEM-PLS). According to Yamin (2009), SEM is a combination of two methods, namely factor analysis (developed in psychological/psychomechanical/sociological analysis) and a simultaneous equation model (developed in econometrics). The use of SEM has the advantage of being able to test complex research models simultaneously and can analyze variables that cannot be measured directly and take into account their errors (Sholihin, 2013). From the whole purpose of this research is an explanatory nature or extends existing theories, so that the SEM analysis used is SEM-PLS. The software used is SmartPLS 3.o.

There are two validities used in SEM, namely convergent and discriminant validity. An indicator can pass the convergent validity test if the loading factor value must be more than 0.7 for confirmatory research, and the loading factor value between 0.6-0.7 for exploratory research is still acceptable and the Average Variance Extracted (AVE) must be greater than 0.5 (Ghazali, 2015). As for passing the validity test, an indicator must have a greater loading value to the construct measured when compared to loading it to another construct (Sholihin, 2013). While reliability testing is carried out in two ways, namely cronbach's alpha and composite reliability. A variable is said to be reliable if it has a value of cronbach's alpha and composite reliability > 0.6 (Ghazali, 2015).

The structural model evaluation begins by looking at the R-square value for each endogenous latent variable as the predictive power of the structural model. According to Ghazali (2015), the R-square 3 value is 0.75 (strong model), 0.50 (moderate model) and 0.25 (weak model). The f-square effect size is calculated as the absolute value of individual contributions for each predictor latent variable on the R-square value of the criterion variable. Size effects can be classified into 3 categories: weak (0.02), medium (0.15) and large (0.35) (Sholihin: 2013). Furthermore, the model evaluation is carried out by viewing at the significance value through a bootstrapping procedure. Where the significance value used is $5 \%$. 


\section{RESULT AND DISCUSSION \\ Characteristics of Respondents}

This research was conducted by distributing questionnaires to 100 samples which are millennial generations. Respondent descriptive statistics are seen in Table 3 which summarizes the research sample based on gender, age, marital status, level of education, occupation, income and domicile.

Based on the research conducted, respondents in this study consisted of $50 \%$ males and $50 \%$ females. In terms of age, the majority of respondents, amounting to $79 \%$ are respondents aged between 21-3 years. Respondents with the second highest number were between $31-38$ years old at $16 \%$. The remaining $5 \%$ are respondents aged between $18-20$ years.

The majority of respondents in this study amounted to $67 \%$ had a status unmarried. As many as $31 \%$ of respondents were married and $2 \%$ of respondents were widow/widower. As for when viewed from the level of education, in general respondents are $\mathrm{S} 1$ graduates at $56 \%$. As many as $22 \%$ of respondents have the last education $\mathrm{S} 2 / \mathrm{S} 3$. As many as $13 \%$ of respondents had a senior high school/ similar education. A total of $7 \%$ of respondents with the latest education in SMK / SMEA. And $2 \%$ of respondents with the last education were D1 / D2 / D3 / D4.

Table 3

Statistics Descriptive ofResearch Samples $(n=100)$

\begin{tabular}{|c|c|c|c|}
\hline & & & $\begin{array}{l}\text { Valid Percent } \\
(\%)\end{array}$ \\
\hline 1 & Gender & $\begin{array}{l}\text { Male } \\
\text { Female }\end{array}$ & $\begin{array}{l}50 \\
50\end{array}$ \\
\hline 2 & Age & $\begin{array}{l}\text { 18-20 Years } \\
21-30 \text { Years } \\
31-38 \text { Years }\end{array}$ & $\begin{array}{r}5 \\
79 \\
16\end{array}$ \\
\hline 3 & Marrital Status & $\begin{array}{l}\text { Married } \\
\text { Unmarried } \\
\text { Widower/Widow }\end{array}$ & $\begin{array}{r}31 \\
67 \\
2\end{array}$ \\
\hline 4 & Level of Education & $\begin{array}{l}\text { SMA/Similar } \\
\text { SMK/Similar } \\
\text { D1/D2/D3/D4 } \\
\text { S1 } \\
\text { S2/S3 }\end{array}$ & $\begin{array}{r}13 \\
7 \\
2 \\
56 \\
22\end{array}$ \\
\hline 5 & Occupation & $\begin{array}{l}\text { Learner/Student } \\
\text { Government employee } \\
\text { Private employee } \\
\text { Enterpreneurship } \\
\text { Housewife } \\
\text { Others }\end{array}$ & $\begin{array}{r}32 \\
14 \\
32 \\
16 \\
4 \\
2\end{array}$ \\
\hline
\end{tabular}

\section{Analysis \\ of Millennial \\ Generation}

275 


\begin{tabular}{|c|c|c|c|c|}
\hline \multirow{16}{*}{276} & \multirow{9}{*}{6} & \multirow{9}{*}{ Income } & $<\operatorname{Rp} 2.000 .000$ & 39 \\
\hline & & & $>$ Rp 2.000.000-Rp 3.000.000 & 19 \\
\hline & & & $>$ Rp 3.000.000-Rp 4.000.000 & 16 \\
\hline & & & $>$ Rp 4.000.000-Rp 5.000.000 & 10 \\
\hline & & & $>$ Rp 5.000.000-Rp 6.000.000 & 5 \\
\hline & & & >Rp 6.000.000-Rp 7.000.000 & 4 \\
\hline & & & >Rp 7.000.000-Rp 8.000.000 & 3 \\
\hline & & & >Rp9.000.000-Rp 10.000.000 & 1 \\
\hline & & & $>\operatorname{Rp} 10.000 .000$ & 3 \\
\hline & & & Special Capital Region of & 13 \\
\hline & & & Jakarta & 19 \\
\hline & & & Banten & 41 \\
\hline & 7 & Domicile & Central Java & 10 \\
\hline & & & West Java & 2 \\
\hline & & & East Java & 5 \\
\hline & & & Special Region of Yogyakarta & 10 \\
\hline
\end{tabular}

Respondents in the study that is equal to $32 \%$ are students or students. Another $32 \%$ are private employees. 16\% are entrepreneurs. 14\% are civil servants. IRT of $4 \%$ and others of $2 \%$. If viewed from the side of the business income per month, the respondent's income is in accordance with the scale of the business he is running. As much as $39 \%$ has an income of $<$ Rp. 2,000,000 per month. As much as 19\% of respondents have income of between Rp. 2,000,000 to Rp. 3,000,000 per month. As many as 16\% of respondents have income between Rp. 3,000,000 to Rp. 4,000,000 per month. A total of $10 \%$ of respondents have income between $\mathrm{Rp} 4,000,000$ to Rp 5,000,000 per month. As much as $5 \%$ of respondents have income between Rp 5,000,000 to Rp 6,000,000 per month. As much as 4\% of respondents have income between $\mathrm{Rp}$ 6,000,000 to $\mathrm{Rp} 7,000,000$ per month. As much as $3 \%$ of respondents have income between $\mathrm{Rp} 7,000,000$ to $\mathrm{Rp} 8,000,000$ per month. As much as $1 \%$ of respondents have income between Rp 9,000,000 to $\mathrm{Rp} 10,000,000$ per month. As many as $3 \%$ of respondents have income of more than Rp 10,000,000 per month.

From the side of domicile, the majority of respondents in the study were domiciled in Central Java, namely $41 \%$ of respondents. The remaining $19 \%$ of respondents reside in Banten; $13 \%$ of respondents reside in Special Capital Region of Jakarta; 10\% of respondents reside in West Java; 2\% of respondents reside in East Java; 5\% of respondents reside in DI Yogyakarta; and $10 \%$ of other respondents are domiciled outside Java Island.

\section{Halal Awareness of Millennial Generation}

Descriptively, it can be seen that the millennial generation's awareness of halal products. Of the 100 respondents in this study, the majority of 
respondents, 52\%, always check halal logos when shopping for products; Analysis $47 \%$ of respondents sometimes check halal logos and $1 \%$ of respondents said they never checked the halal logo at all when shopping. Based on these data it can be said that the millennial generation cared enough about halal products.

Table 4

\section{Logo Halal Checking When Shopping}

\begin{tabular}{lll}
\hline No. & Variable & Valid Percent \\
\hline 1 & Always & 52 \\
2 & Seldom & 47 \\
3 & Never & 1 \\
\hline
\end{tabular}

Of the 100 respondents, $85 \%$ of the millennial generation already know the legitimate halal logo used in Indonesia. Although there are 15\% of respondents who still do not know the halal logo that is legitimately used in Indonesia.

Table 5 Knowledge of Halal Logo

\begin{tabular}{lll}
\hline No. & Variable & Valid Percent \\
1 & Right & 85 \\
2 & False & 15 \\
\hline
\end{tabular}

\section{Behavior of Millennial Generation in Utilizing Technology}

Millennials are generations who generally use technology to carry out all their activities. Based on a survey conducted on 100 millennial generation respondents, it can be known that not all millennials prefer technology facilities in buying and selling transactions. This can be seen from the results of survey that $53 \%$ of respondents said they did not agree when using technology facilities in the payment of certain products. Technology facilities in this case are like e-money, transfers, use of EDC machines and so on. In terms of product ordering, as many as $44 \%$ of respondents agreed that when using technology facilities, $10 \%$ of respondents said that they strongly agreed even though $43 \%$ of other respondents claimed to disagree even $3 \%$ of respondents said they strongly disagreed. Ordering products using technology means using the facilities from Gojek or Grab or via e-commerce and so on. While when asked about online shopping, $58 \%$ of respondents disagree if online shopping is more popular than direct shopping. Although on the other hand as many as 33\% of respondents claimed to prefer online shopping rather than direct shopping. 
IQTISHADIA

12,2

278
Table 6

Using Facilities of Technology in Shopping

\begin{tabular}{|c|c|c|c|}
\hline & & & Valid Percent (\%) \\
\hline 1 & Payment & $\begin{array}{l}\text { Highly Disagree } \\
\text { Not Agree } \\
\text { Agree } \\
\text { Highly Agree }\end{array}$ & $\begin{array}{r}2 \\
53 \\
33 \\
12\end{array}$ \\
\hline 2 & Ordering & $\begin{array}{l}\text { Highly Disagree } \\
\text { Not Agree } \\
\text { Agree } \\
\text { Highly Agree }\end{array}$ & $\begin{array}{r}3 \\
43 \\
44 \\
10\end{array}$ \\
\hline 3 & $\begin{array}{l}\text { Online } \\
\text { Shopping }\end{array}$ & $\begin{array}{l}\text { Highly Disagree } \\
\text { Not Agree } \\
\text { Agree } \\
\text { Highly Agree }\end{array}$ & $\begin{array}{r}3 \\
58 \\
33 \\
6\end{array}$ \\
\hline
\end{tabular}

\section{SEM-PLS Result}

There are two validity tests in this study, namely convergent validity and discriminant validity. Convergent validity test aims to see the correlation between the indicators used in a construct. Convergent validity test can be seen from the value of loading factor and the value of Average Variance Extracted (AVE). While the discriminant validity test aims to see the correlation between indicators in one construct with indicators from other constructs. The validity test can be seen from the cross loading value.

Table 7

Nilai Loading Factor

\begin{tabular}{|c|c|c|c|c|}
\hline No. & Variable & Indicator & $\begin{array}{l}\text { Loading } \\
\text { Factor }\end{array}$ & Remark \\
\hline 1 & Buying Interest & $\begin{array}{l}\text { BI1 } \\
\text { BI2 } \\
\text { BI3 }\end{array}$ & $\begin{array}{l}0.898 \\
0.940 \\
0.897\end{array}$ & $\begin{array}{l}\text { Valid } \\
\text { Valid } \\
\text { Valid }\end{array}$ \\
\hline 2 & Consumer Satisfaction & $\begin{array}{l}\text { CS1 } \\
\text { CS2 } \\
\text { CS3 } \\
\text { CS4 }\end{array}$ & $\begin{array}{l}0.749 \\
0.805 \\
0.830 \\
0.678\end{array}$ & $\begin{array}{l}\text { Valid } \\
\text { Valid } \\
\text { Valid } \\
\text { Valid }\end{array}$ \\
\hline 3 & Islamic Branding & $\begin{array}{l}\text { IB1 } \\
\text { IB2 } \\
\text { IB3 } \\
\text { IB4 } \\
\text { IB5 }\end{array}$ & $\begin{array}{l}0.709 \\
0.645 \\
0.796 \\
0.771 \\
0.735\end{array}$ & $\begin{array}{l}\text { Valid } \\
\text { Valid } \\
\text { Valid } \\
\text { Valid } \\
\text { Valid }\end{array}$ \\
\hline 4 & Price & $\begin{array}{l}\text { P1 } \\
\text { P2 } \\
\text { P3 }\end{array}$ & $\begin{array}{l}0.851 \\
0.858 \\
0.900\end{array}$ & $\begin{array}{l}\text { Valid } \\
\text { Valid } \\
\text { Valid }\end{array}$ \\
\hline
\end{tabular}




\begin{tabular}{cccc} 
& & & \\
& R1 & 0.805 & Valid \\
R2 & Religiosity & 0.783 & Valid \\
& R3 & 0.764 & Valid \\
& R4 & 0.859 & Valid \\
& R5 & 0.854 & Valid \\
\hline
\end{tabular}

Based on Table 7 , the value of loading factor of all indicators used is $>$ o.6, which means that the indicator passes the discriminant validity test (Ghazali, 2015). In addition to the value of the loading factor, the convergent validity test can also be seen through the AVE value. According to Ghazali (2015), to pass the convergent validity test, the AVE value must be> 0.5 . Based on Table 8 , it can be seen that all varaibel have AVE value> 0.5 , this proves that the variable has passed the second convergence test. Then it can be concluded that all indicators and variables used have fulfilled the test requirements for convergent validity.

Table 8

Value of Average Variance Extracted (AVE)

\begin{tabular}{llll}
\hline No. & Variable & AVE & Remark \\
\hline 1 & Buying Interest & 0.832 & Valid \\
2 & Consumer Satisfaction & 0.590 & Valid \\
3 & Islamic Branding & 0.537 & Valid \\
4 & Price & 0.756 & Valid \\
5 & Religiosity & 0.663 & Valid \\
\hline
\end{tabular}

As for testing the validity of discriminant can be seen through the cross loading value by comparing the value of loading the construct itself with the loading value to another construct. According to Sholihin (2013), the value of loading the indicator to the measured construct must be greater than the loading value to another construct. Based on Table 9, it can be seen that all loading indicators (which are parentheses) have a value greater than the value of loading to another construct (which is not given parentheses). This shows that all indicators used in this study have passed the discriminant validity test. It can be interpreted that different construct measurements are not highly correlated.

Table 9

Value of Cross Loading

\begin{tabular}{lllllll}
\hline No & & $\begin{array}{l}\text { Buying } \\
\text { Interest }\end{array}$ & $\begin{array}{l}\text { Consumer } \\
\text { Satisfaction }\end{array}$ & $\begin{array}{l}\text { Islamic } \\
\text { Branding }\end{array}$ & Price & Religiosity \\
\hline 1 & BI1 & $(0.898)$ & 0.477 & 0.410 & 0.259 & 0.593 \\
& BI2 & $(0.940)$ & 0.551 & 0.455 & 0.257 & 0.508 \\
& BI3 & $(0.897)$ & 0.590 & 0.492 & 0.319 & 0.490 \\
2 & CS1 & 0.508 & $(0.749)$ & 0.553 & 0.400 & 0.501
\end{tabular}




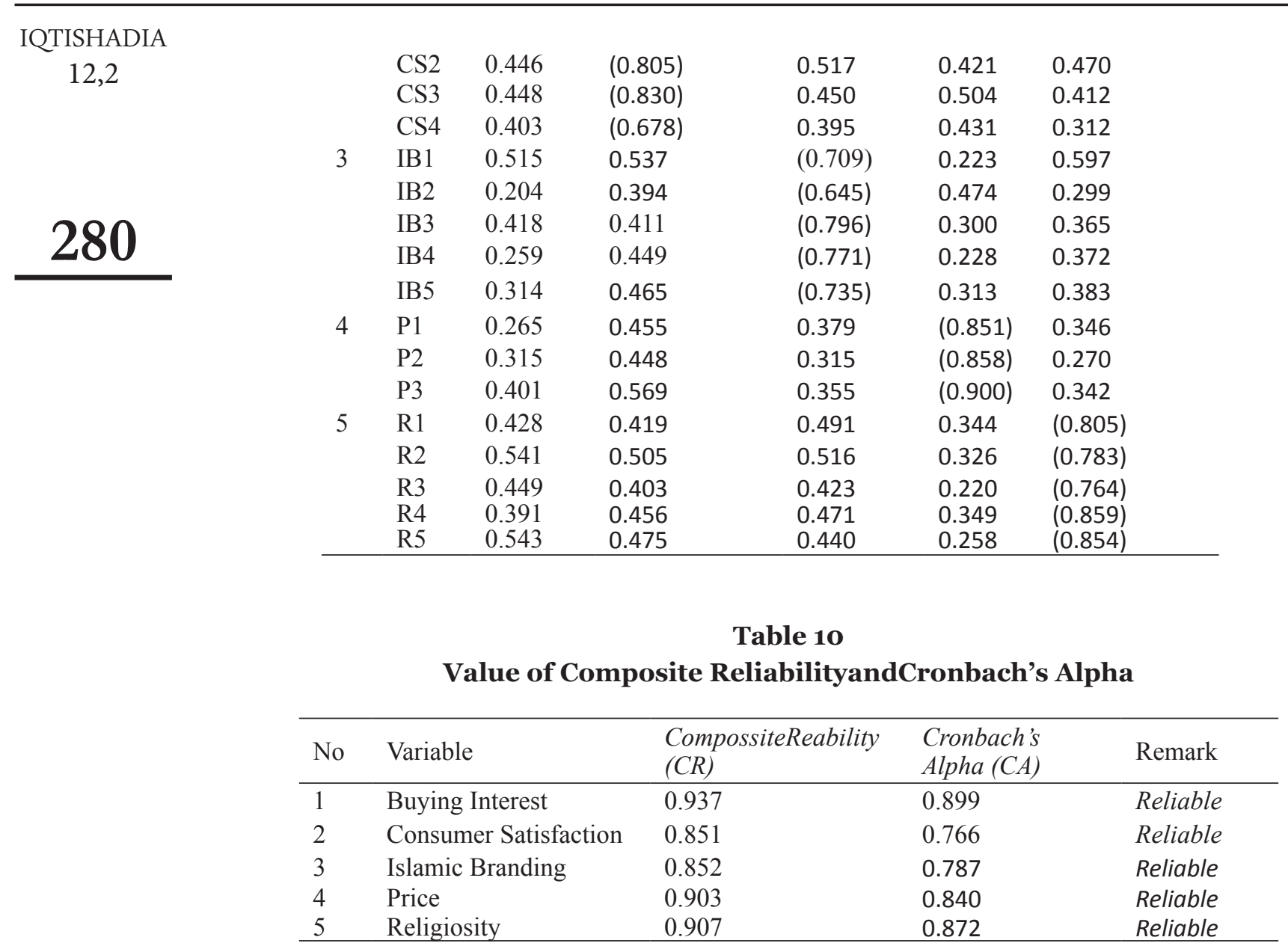

Reliability testing can be seen through cronbach's alpha and composite reliability. According to Ghazali (2015), the value of cronbach's alpha and composite reliability must be greater than 0.6 to pass the reliability test. In Table 9 it can be seen that all the variables used have a value greater than 0.6 both the value of cronbach's alpha and the composite reliability value. This shows that all variables in this study are reliable and have good accuracy, consistency and accuracy in measuring each construct in this study.

According to Ghazali (2015), the value of R-Square can be classified into 3 types: strong model (0.75), moderate model (0.50) and weak model (0.25). The R-Square value serves to see each endogenous latent variable as the predictive power of the structural model. Changes in R-Squares values can be used to explain certain exogenous latent variables against endogenous latent variables. Based on Table 10 it can be seen that: First, the buying interest variable has a value of R-Square 0.380 belonging to the weak category. That is, that the variance of the buying interest variable can be explained by variables in the model namely Islamic branding, religiosity and price by $38 \%$. While the remaining $62 \%$ is explained by other variables outside the model. 


\begin{tabular}{lllll}
\hline No & VariableCriterion & VariablePredictor & $R$ Square & Remark \\
\hline \multirow{2}{*}{$\begin{array}{l}\text { Buying Interest } \\
\text { Consumer Satisfaction }\end{array}$} & $\begin{array}{l}\text { Islamic Branding } \\
\text { Religiosity } \\
\text { Price }\end{array}$ & $\begin{array}{l}\text { Islamic Branding } \\
\text { Religiosity } \\
\text { Price }\end{array}$ & 0.380 & Weak \\
2 & Religiosity & Islamic Branding & 0.547 & Moderat \\
3 & & & Weak \\
\hline
\end{tabular}

Second, the customer satisfaction variable has a value of R-Square 0.547 which is classified as moderate. That is, that the variance of the consumer satisfaction variable can be explained by variables in the model namely Islamic branding, religiosity and price by $54.7 \%$. While the remaining 45.3\% is explained by other variables outside the model. Third, the religiosity variable has a value of $\mathrm{R}$-Square 0.334 which is classified as weak. That is, that the variance of religiosity variables can be explained by variables in the model that is Islamic branding by $33.4 \%$. While the remaining $66.6 \%$ is explained by other variables outside the model.

According to Sholihin (2013), the effect size or f-squared effect size is divided into 3 categories, namely weak (0.02), medium (0.15) and large (o.35). The value of $\mathrm{f}$-squared effect size serves to see the magnitude of the contribution of each latent variable predictor on the R-squared value of the criterion variable. In Table 11 can be seen the value of each f-squared effect size of the predictor variable. First, buying interest variables have predictor variables namely Islamic branding (0.049), price (0.004) and religiosity (o.197). This means that the contribution of Islamic branding variables to the R-squared variable buying interest is small, that is equal to $4.9 \%$; the contribution of the price variable to the R-squared variable buying interest is small, that is equal to $0.4 \%$; the contribution of the variable religiosity to the R-squared variable buying interest is classified as medium that is equal to $19.7 \%$.

Table 12

Nilai F-Squared Effect Size

\begin{tabular}{|c|c|c|c|c|}
\hline No & Variable & $\begin{array}{l}\text { Buying } \\
\text { Interest }\end{array}$ & $\begin{array}{l}\text { Consumer } \\
\text { Satisfaction }\end{array}$ & Religiosity \\
\hline 1 & $\begin{array}{l}\text { Islamic } \\
\text { Branding }\end{array}$ & 0.049 & 0.180 & 0.501 \\
\hline 2 & Price & 0.004 & 0.210 & \\
\hline 3 & Religiosity & 0.197 & 0.071 & \\
\hline
\end{tabular}


IQTISHADIA

12,2

282

Second, consumer satisfaction variables have predictor variables, namely Islamic branding (0.180), price (0.210) and religiosity (0.071). This means that the contribution of Islamic branding variables to the R-squared variable consumer satisfaction is classified as medium that is equal to $18 \%$; the contribution of the price variable to the $\mathrm{R}$-squared variable consumer satisfaction is classified as medium that is equal to $21 \%$; the contribution of the religiosity variable to the $\mathrm{R}$-squared variable consumer satisfaction is classified as weak, which is $7.1 \%$. Third, the religiosity variable has a predictor variable that is Islamic branding of 0.501. This means that the contribution of the Islamic branding variable to the $\mathrm{R}$-squared variable religiosity is relatively large at $50.1 \%$.

Significance values can be seen through a bootstrapping procedure. Figure 3 and Figure 4 are PLS algorithm and bootstrapping outputs. The PLS algorithm is used to see the magnitude of the path coefficient values between latent variables, while the bootstrapping output is used to view the magnitude of the t-statistical significance value.

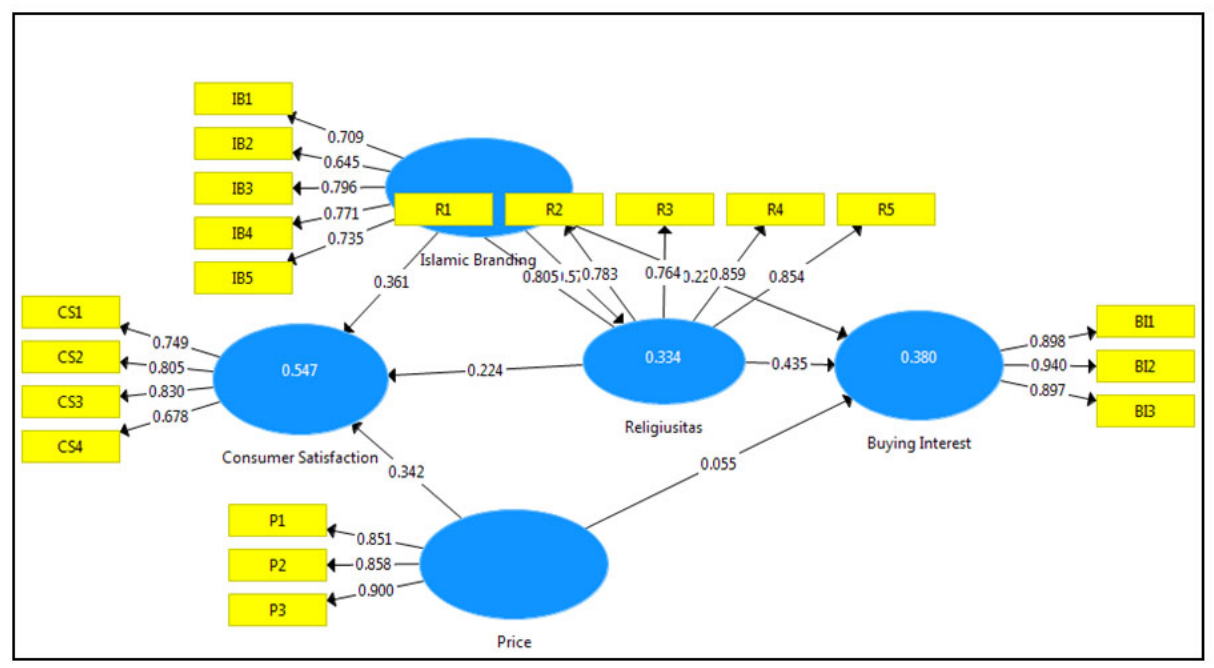

Fig. 3. Output of PLS Alghorithm

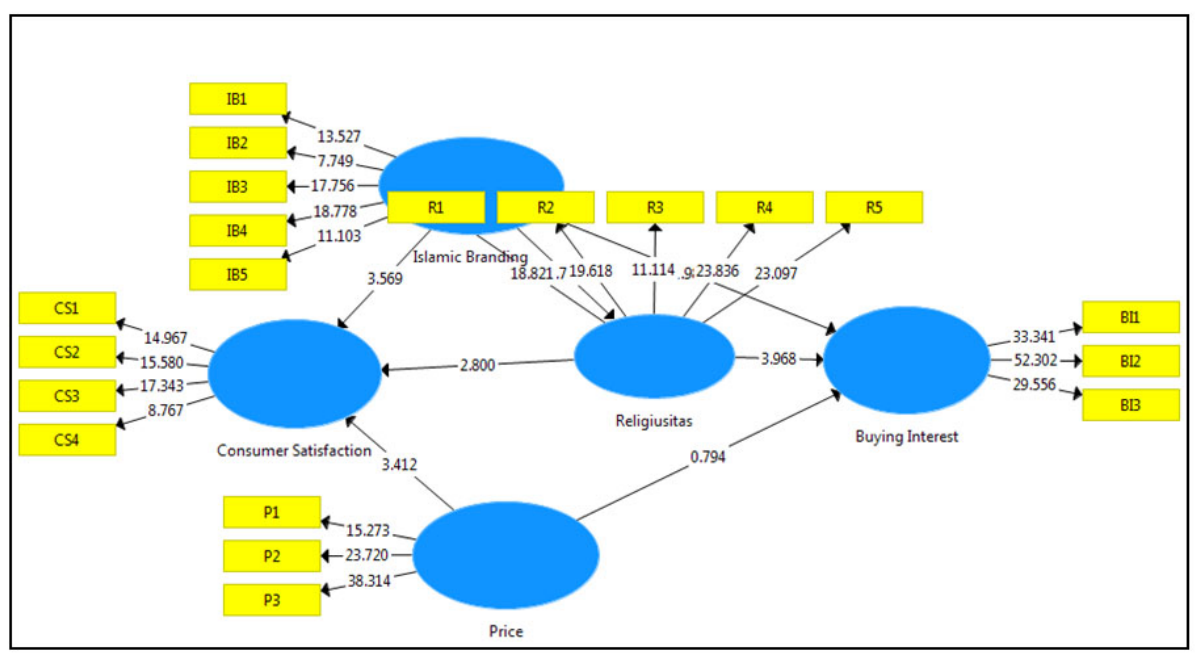

Figure 4. Output of PLS Bootstrapping 
From the two figures above, basically it can be seen the magnitude of the path coefficient and T-statistics. However, to be more clear about the significance can be seen in Table 12.The significance value used in this study is $5 \%$. Based on Table 12, it can be seen that significant variables are: First, Islamic branding variables have a positive and significant effect on buying interest variables. This can be seen from the path coefficient value of 0.221 and p-value of 0.048 which is smaller than 0.05. Second, Islamic branding variables have a positive and significant effect on consumer satisfaction variables. This can be seen from the path coefficient value of 0.361 and $p$-value of 0.000 which is smaller than 0.05. Third, Islamic branding variables have a positive and significant effect on religiosity variables. This can be seen from the path coefficient value of 0.578 and p-value of 0.000 which is smaller than 0.05.

Table 13

Value of F-Squared Effect Size

\begin{tabular}{|c|c|c|c|}
\hline No & Variable & $\begin{array}{l}\text { Original Sample } \\
\text { (O) }\end{array}$ & P Values \\
\hline 1 & Islamic $\longrightarrow$ Branding Buying Interest & 0.221 & $0.048^{*}$ \\
\hline 2 & $\begin{array}{l}\text { Islamic } \longrightarrow \text { Branding Consumer } \\
\text { Satisfaction }\end{array}$ & 0.361 & $0.000^{*}$ \\
\hline 3 & Islamic $\longrightarrow$ Branding Religiusitas & 0.578 & $0.000^{*}$ \\
\hline 4 & Price $\longrightarrow$ Buying Interest & 0.055 & 0.427 \\
\hline 5 & Price $\longrightarrow$ Consumer Satisfaction & 0.342 & $0.001^{*}$ \\
\hline 6 & Religiosity $\longrightarrow$ Buying Interest & 0.435 & $0.000^{*}$ \\
\hline 7 & Religiosity $\longrightarrow$ Consumer Satisfaction & 0.224 & $0.005^{*}$ \\
\hline
\end{tabular}

Fourth, the price variable has a positive and significant effect on the variable consumer satisfaction. This can be seen from the path coefficient value of 0.342 and p-value of 0.001 which is smaller than 0.05. Fifth, religiosity variables have a positive and significant effect on buying interest variables. This can be seen from the path coefficient value of 0.432 and p-value of 0.000 which is smaller than 0.05. Sixth, religiosity variables have a positive and significant effect on consumer satisfaction variables. This can be seen from the path coefficient value of 0.224 and p-value of 0.005 which is smaller than 0.05 .

Table 14

Value of Indirect Effect

\begin{tabular}{llll}
\hline No & Variable & $\begin{array}{l}\text { Original Sample } \\
(\mathrm{O})\end{array}$ & P Values \\
\hline 1 & $\begin{array}{l}\text { Islamic Branding } \longrightarrow \text { Religiosity } \longrightarrow \text { Buying } \\
\text { Interest }\end{array}$ & 0.251 & $0.001^{*}$ \\
2 & $\begin{array}{l}\text { Islamic Branding } \longrightarrow \text { Religiosity } \longrightarrow \\
\text { Consumer Satisfaction }\end{array}$ & 0.129 & $0.013^{*}$ \\
\hline
\end{tabular}


IQTISHADIA

12,2

284

As for viewing the significance of mediating variables can be seen through the indirect effect value. In Table 12 shows that there are two significant equations: First, Islamic branding variables indirectly have a positive and significant effect on buying interest variables through religiosity variables. This can be seen from the path coefficient value of 0.251 and p-value of 0.001 which is smaller than 0.05. Second, the Islamic branding variable indirectly has a positive and significant effect on consumer satisfaction variables through religiosity variables. This can be seen from the path coefficient value of 0.129 and p-value of 0.013 which is smaller than 0.05 .

\section{Discussion of the Research Results}

Based on the analysis that has been done, this research gives the result that Islamic branding and religiosity can influence buying interest positively and significantly among millennial. This illustrates that the higher the Islamic branding on a product and the higher level of millennial generation religiosity, the more buying interest in halal products will increase. The results of these studies can be considered by business practitioners who are concerned in developing halal products. Where business practitioners can increase buying interest among millennial by using product marketing strategies through increasing Islamic branding. Indicators of Islamic branding in this study are such as including the halal logo on the product, having a halal product certificate issued by a legal institution, using the product name in Islamic terms, conducting customer service with Islamic ethics and so on. The target marketing of halal products is millennial generation which has a fairly high level of religiosity.

Another implication of this research is that consumer satisfaction in millennial generation is also influenced by Islamic branding, religiosity and price. This means that consumer satisfaction in millennial generation is influenced by Islamic branding and product prices. In addition, it is also influenced by the level of religiosity of each individual. This illustrates that millennial who have high religiosity will tend to have high satisfaction when consuming halal products. This condition is a positive target for business practitioners of halal products in determining target markets and marketing strategies.

Broadly speaking and through further analysis, this study has findings that Islamic branding can positively influence buying interest and satisfaction with the consumption of halal products that millennial feel through the variable of religiosity. Therefore Islamic branding is important to be applied 
by companies interested in developing business in the halal industry sector and making millennial who have high religiosity as the main target market. As for what is meant by Islamic branding in this research are products that have the halal logo, use the terms Arab/sharia/Islam/halal, apply Islamic values in running a business, channel a portion of the profits obtained by the company to social funds, promotion to memorize al Qur'an or reader of the Qur'an and so forth.

\section{CONCLUSION}

Based on the results of SEM-PLS analysis, it can be seen that Islamic branding and religiosity variables have a positive and significant influence on buying interest variables. In addition, Islamic branding, religiosity and price variables have a positive and significant influence on consumer satisfaction variables. This means that the millennial generation's buying interest in consuming halal products can be influenced by Islamic branding factors used by producers or companies and can also be influenced by the religiosity of each individual. In addition, in terms of satisfaction the millennial generation perceives when consuming halal products is strongly influenced by the company's Islamic branding, the individual's religiosity and the prices labeled on the product. If we look further, Islamic branding also can positively influence buying interest and satisfaction will consume halal products that the millennial generation feels through religiosity variables. Therefore, Islamic branding is important to be implemented by companies interested in developing business in the halal industry sector. As for the use of the technology used, the millennial generation cannot be recognized, all of them like technology in carrying out all its activities. There are still many millennial generations who prefer manual or conventional methods of product payment and ordering. The implication of this research can be used as a reference by entrepreneurs in studying consumption behavior among millennials in particular relating to halal products.

\section{References}

Aditi, Bunga. (2017). Analisis Pengaruh Inovasi Produk,Harga, Dan Sertifikasi Halal Terhadap Minat Beli Ulang Melalui Kepuasan Konsumen UMKM di Kota Medan: Proceedings Roundtable For Indonesian Entrepreseurship Educators, 40-52.

Adiba, Elfira Maya dkk. (2018). Pengaruh Halal Knowledge, Islamic Religiosity, dan Attitude terhadap Behavior Konsumen Muslim 
IQTISHADIA

12,2

286

Generasi Y Pengguna Kosmetik Halal di Surabaya INOBIS: Jurnal Inovasi Bisnis dan Manajemen Indonesia, 1 (3), Juni 2018.

Astogini, Dwiwiyati dkk. (2011). Aspek Religiusitas dalam Keputusan Pembelian Produk Halal. Jurnal JEBA, 13 (1).

Baker, Ahmad. (2010). On Islamic Branding: Brands as Good Deeds. On Journal of Islamic Marketing, 1 (2): 101-106.

Elasrag, H. (2016). Halal Industry: Key Challenges and Opportunities. Available at SSRN: https://ssrn.com/abstract=2735417.

Ferdinand, Augusty. (2006). Metode Penelitian Managemen. Semarang: Badan Penerbit Undip.

Ghazali, Imam. (2015). Partial Least Squares; Konsep, Tekhnik dan Aplikasi Menggunakan Program Smart PLS 3.o. Semarang: Badan Penerbit Undip.

Goldmansach. (2017). Millenials Coming Of Age, from http://www. goldmansachs.com/ourthinking/pages/millennials/.

Haider, Hayat Muhammad Awan Ahmad Nabeel Siddiquei Zeeshan. (2015). Factors affecting Halal purchase intention - evidence from Pakistan's Halal food sector", Management Research Review, 38 (6).

Kotler, Philip. (2009). Marketing Management Edisi 13. Surabaya: Erlangga.

Kotler, Philip. (2005). Manajemen Pemasaran, jilid 1. Jakarta: Prenhallindo

Nasrullah, Muhammad. (2015). Islamic Branding, Religiusitas dan Keputusan Konsumen Terhadap Produk. Jurnal Hukum Islam (JHI), 13 (2): $79-87$.

Stitou, Nora \& Rezgui, Heinen. (2012). The Muslim Consumer as the Key Player in Halal, ASIDCOM Investigations 201O-2012. ASIDCOM Report.

Syahputra, Adi dan Haroni Doli Hamoraon. (2013). Pengaruh Labelisasi Halal Terhadap Keputusan Masyarakat Kecamatan Perbaungan Dalam Pembelian Produk Makanan Dalam Kemasan. Jurnal Ekonomi dan Keuangan Vol.2 No.8.

Sungkar, I. (2007, 25 Oktober). Livestock Asia 2007, Exhibition \& Seminar Halal Hub Session.

Suryani, Tatik. (2012). Perilaku Konsumen; Implikasi pada Strategi Pemasaran. Yogyakarta: Graha Ilmu. 
Umar, Husein. (2011). Metode Penelitian untuk Skripsi dan Thesis Bisnis. Jakarta: Rajagrafindo Persada.

Analysis of Millennial

Generation

Walker, M., Buchta, D., Reuter, T., \& Gott, J. (2007). Addressing the Muslim Market: Can You Afford Not To?. Illinois: AT Kearney.

Wijanto, Setyo Hari. (2008). Structural Equation Modeling. Yogyakarta: Graha Ilmu. 